\title{
SPECIFICS OF TRAINING FUTURE RESERVE OFFICERS FOR EDUCATIONAL WORK IN THE ARMED FORCES OF UKRAINE
}

\section{СПЕЦИФІКА ПІДГОТОВКИ МАЙБУТНІХ ОФІЦЕРІВ ЗАПАСУ ДО ВИХОВНОЇ РОБОТИ У ЗБРОЙНИХ СИЛАХ УКРӒ̈НИ}

\section{Taras Inozemtsev ${ }^{1}$}

\section{Alla Khomenko}

DOI: https://doi.org/10.30525/978-9934-26-001-8-1-5

Abstract. The subject of the article is the preparation of future reserve officers for educational work. The training of reserve officers is carried out by the military departments of higher education institutions of Ukraine. The article contains information that citizens of Ukraine undergo military training on a voluntary basis who have or receive a higher education degree at least a bachelor's degree, fit for military service for health reasons and moral and business qualities. Citizens can undergo military training, subject to the correspondence of the specialties that they or for which they are trained in the institution of higher education, the military accounting specialty, in which the training of reserve officers is carried out.

The leading feature of the military professional activity of a military leader is the dominant professional orientation, which manifests itself in an orientation toward working with personnel and active interpersonal interaction, toward organizing activities, toward tough interaction with the enemy.

In this regard, the officer must have a broad developed practical thinking and managerial competence. The article presents the components of its formation and demonstrates the ways to achieve it: informationanalytical component of training future reserve officers; the formation of the communicative competence of future reserve officers; the use of

\footnotetext{
${ }^{1}$ Graduate Student of the Department of Pedagogy and Andragogy of

Poltava National Pedagogical University named after V.G. Korolenko, Ukraine

${ }^{2}$ Candidate of Pedagogical Sciences,

Associate Professor of the Department of Pedagogy and Andragogy of

Poltava National Pedagogical University named after V.G. Korolenko, Ukraine
} 
computer technology in training reserve officers for educational work; individualization of training.

The information and analytical component of the training of future reserve officers provides for: 1) information and presentation meetings of candidates for training under the training program for reserve officers with officers of the military commissariat; 2) professional excursions and to military units of candidates for training under the training program for reserve officers, in which potential applicants can communicate with platoon commanders and company commanders, get acquainted with the daily activities of the platoon; 3) self-testing of potential applicants for professional self-determination and readiness for management activities.

The formation of the communicative competence of reserve officers provides for the following factors: pedagogy of cooperation, personalityoriented education, an active personal position of the future reserve officer, critical thinking, the formation of language culture and the influence of mentors.

One of the effective means of improving the level of training of military specialists is the use of modern information technologies, in particular, virtual computer systems and computer networks (simulation) models. They, first of all, should contribute to the comprehension and assimilation of educational material, as well as to ensure the possibility of a comprehensive assessment of the readiness of the future reserve officer for independent activity, the timely introduction of individual adjustments in the training of a military specialist.

The main methodological foundations of the process of individualization of training: the organization of additional classes with students who have gaps in knowledge, by organizing optional classes; search for ways to individualize learning within a specific lesson; inclusion of the weak in the subgroups of well-prepared students.

The practical application of these theoretical principles will contribute to the formation of a military specialist and the preparation of future reserve officers for educational work.

\section{1. Вступ}

Військова освіта - необхідна та невід'ємна складова військової організації держави. Вона $є$ основним джерелом підготовки та комплектування Збройних Сил України, інших військових формувань і пра- 
воохоронних органів висококваліфікованими офіцерськими кадрами. Система військової освіти повинна забезпечувати підготовку військових фахівців із високим рівнем професіоналізму, компетентності, інтелектуального розвитку, загальної та військово-професійної культури, здатних із високою ефективністю виконувати поставлені завдання щодо оборони Вітчизни, розвитку власної творчої індивідуальності, наполегливого самостійного засвоєння нових знань протягом військової служби.

Підготовка громадян для такої служби - резервістів, має на меті формування військово-навчених осіб для забезпечення, в першу чергу, потреб Збройних Сил. У цьому напрямі працюють як спеціальні військові заклади освіти, так і певна частина закладів вищої освіти - осередків підготовки майбутніх офіцерів з різних військових спеціальностей, здатних не лише до служби у військовому резерві, а й до роботи в силових структурах, відомствах і установах, де при працевлаштуванні вимагається наявність офіцерського звання.

Успішність професійної діяльності майбутніх офіцерів запасу пов'язана зі змістом і рівнем інтенсивності прояву мотивів, цілей, умов і способів службово-педагогічної діяльності, які різняться залежно від етапів професіоналізації і кваліфікації фахівців. Навчання студентів кафедри підготовки офіцерів запасу закладу вищої освіти є процесом засвоєння основних уявлень та схем майбутньої службово-педагогічної діяльності. Її ефективність безпосередньо залежить від особливості формування та розвитку мотиваційної сфери особистості майбутнього офіцера запасу у процесі його професіоналізації. Мотивація студентів кафедри підготовки офіцерів запасу залежить від спрямованості освітньо-виховного процесу на сучасні вимоги розвитку військової освіти, визначення обсягу і змісту навчання майбутніх офіцерів запасу, впровадження цілісної системи їх підготовки відповідно до освітніх стандартів вищої військової освіти [10, с. 353-354].

Отже, мета нашої статті теоретично обгрунтувати складові підготовки майбутніх офіцерів запасу до виховної роботи у Збройних Силах України як специфічного навчально-виховного процесу.

Методологічною основою нашого наукового пошуку є методи теоретичного дослідження: функціональний та системно-структурний аналіз, що дає можливість обгрунтувати певну цілісність цього педа- 
гогічного процесу і визначити зміст та обсяг його компонентів, які входять у педагогічну підготовку майбутніх офіцерів запасу, а також особливості реалізації кожного з них саме у цій педагогічній системі. У своїй сукупності ці компоненти утворюють якісно новий педагогічний процес. Він може розглядатися як закономірно обумовлений, внутрішньо цілісний, керований педагогічний процес підготовки майбутніх офіцерів запасу до виховної роботи. Під підготовкою майбутніх офіцерів запасу до виховної роботи з особовим складом ми розуміємо системний специфічний педагогічний процес, змістом якого є синтез навчання, виховання, розвитку майбутніх офіцерів запасу, їх психологічної підготовки до виховної діяльності і педагогічного самовдосконалення, а результатом - опанування ними змісту цієї підготовки, тобто готовність до виховної діяльності у підрозділі.

Виховна робота у Збройних Силах та інших військових формуваннях України - це система організаційних, морально-психологічних, інформаційних, педагогічних, правових, культурно-просвітницьких та військово-соціальних заходів, спрямованих на формування і розвиток у воїнів професійно необхідних якостей, моральної самосвідомості, що має забезпечити високу бойову і мобілізаційну готовність органів управління, з'єднань і частин, зміцнення військової дисципліни та правопорядку, згуртування військових колективів. Тому майбутні офіцери запасу повинні отримати відповідну підготовку та практичні навички здійснювати іiі.

Ми погоджуємось 3 твердженням науковці [22; 23], що якість підготовки майбутніх офіцерів запасу не повною мірою задовольняє потреби Збройних Сил України щодо їх функціонування в мирний час, а також застосування в бойових і наближених до них умовах. Розвиток системи військової освіти стримує низка таких основних причин і проблем: валовий характер підготовки фахівців, певне ігнорування особистості, неповне розкриття й використання здібностей студентів майбутніх офіцерів запасу та відсутність у них зацікавленості в цьому; певна девальвація цінностей вищої освіти, ії̈ елітарності в аспекті розвитку інтелектуального рівня особистості та їі статусу, що має гарантувати особистості відповідну соціальну роль; недостатня інтеграція 3 фундаментальною та прикладною наукою, сучасними інноваційними технологіями, що відповідають кращим світовим зразкам; переванта- 
женість змісту навчання; ігнорування психофізіологічних рекомендацій стосовно можливостей засвоєння курсантами, визначених обсягів навчального матеріалу та ін.

Вважаємо, що подоланню вище вказаних проблем сприятиме наступна структура процесу підготовки офіцерів запасу до виховної роботи: інформаційно-аналітична складова визначення студента щодо його підготовки як майбутнього офіцера запасу; формування комунікативної компетентності майбутніх офіцерів запасу; використання комп’ютерних технологій при підготовці офіцерів запасу до виховної роботи; індивідуалізація навчання.

\section{2. Порядок підготовки офіцерів запасу}

Добровільна служба у військовому резерві [19] є видом виконання військового обов'язку, передбаченим Державною програмою розвитку Збройних Сил України [15].

На даний час підготовка офіцерів запасу здійснюється у закладах вищої освіти відповідно до Положення про військові навчальні підрозділи закладів вищої освіти, затвердженого наказом Міністерства освіти і науки України, Міністерства оборони України № 910/412 від 15 серпня 2018 року [17].

Це Положення визначає повноваження органів управління військовими навчальними підрозділами (військові інститути, військові коледжі, факультети, відділення військової підготовки, кафедри військової підготовки, кафедри медицини катастроф та військової медицини) закладів вищої освіти, особливості організації та здійснення освітньої діяльності в них, порядок проходження особовим складом військової служби, використання військового майна, озброєння та військової техніки.

Положення поширює свою дію на заклади вищої освіти незалежно від їх підпорядкування, у структурі яких функціонують військові навчальні підрозділи.

Це Положення розроблено відповідно до Законів України «Про освіту», «Про вищу освіту», «Про військовий обов'язок і військову службу», постанови Кабінету Міністрів України від 01 лютого 2012 року № 48 «Про затвердження Порядку проведення військової підготовки громадян України за програмою підготовки офіцерів запасу» (зі змінами) [18]. 
Військову підготовку на добровільних засадах проходять громадяни України, які мають або здобувають ступінь вищої освіти не нижче бакалавра, придатні до військової служби за станом здоров'я та морально-діловими якостями.

Громадяни можуть проходити військову підготовку за умови відповідності спеціальностей, які вони мають або за якими здійснюється їх підготовка у закладі вищої освіти, військово-обліковій спеціальності, за якою проводиться підготовка офіцерів запасу.

Метою проведення військової підготовки є забезпечення Збройних Сил, інших військових формувань, а також правоохоронних органів спеціального призначення та Держспецтрансслужби (далі - Збройні Сили та інші військові формування) необхідною кількістю військовонавчених громадян для виконання військового обов'язку в запасі, проходження військової служби за контрактом або за призовом осіб офіцерського складу, проходження служби у військовому резерві Збройних Сил та інших військових формувань, а також забезпечення реалізації права громадян на рівні можливості у виборі професії шляхом здобуття додаткових знань, умінь і навичок, необхідних для належного виконання військового обов'язку в запасі у мирний час, обов'язків військової служби у воєнний час та для майбутньої професійної діяльності.

Здобувачі вищої освіти закладів вищої освіти, що не мають військових навчальних підрозділів, можуть проходити військову підготовку у закладах вищої освіти, що мають такі підрозділи, та у вищих військових навчальних закладах. На даний час таку підготовку здійснюють більше 50 навчальних закладів України. Перелік закладів вищої освіти, на базі яких проводиться військова підготовка, наведений в додатку до Порядку проведення військової підготовки громадян України за програмою підготовки офіцерів запасу (зі змінами) [18].

Особливостями діяльності майбутнього офіцера запасу згідно 3 класифікацію, запропонованою Є. Староконем є: своєрідність цілей і результатів (певний рівень морально-психологічного стану особового складу та умови його самовдосконалення); особливий характер об'єкту впливу (особовий склад військової частини і види його діяльності); регламентованість (підпорядкованість командиру і старшому органу управління виховним процесом); специфічність 
засобів діяльності (вербальні, технічні засоби виховання, соціально-психологічні й педагогічні технології впливу на предмет діяльності тощо); інтенсивність функціонування психіки та висока інтелектуальна напруженість під час реалізації основних функцій своєї діяльності [5, с. 12].

Перелік цих особливостей доводить, що не кожна людина може бути підготовлена до такої діяльності. Вважаємо, що залучення студентів до навчання на кафедрі військової підготовки слід починати 3 інформаційно-аналітичного компонента.

\section{3. Інформаційно-аналітичний компонент підготовки майбутніх офіцерів запасу}

Інформаційно-аналітичний компонент підготовки сучасного фахівця є важливою складовою більшості сучасних професій, включаючи й ті, що пов'язані з діяльністю збройних сил, силових структур, відомств і установ України. Щодо потенційних вступників на навчання за програмою підготовки офіцерів запасу, то слід зазначити недостатній інформаційно-аналітичний супровід, зорієнтований на прийняття ними відповідного рішення. Переважає формальне ознайомлення кандидатів на навчання з основними документами: Законом України “Про військовий обов'язок і військову службу”; Указом Президента України "Про Положення про проходження громадянами України військової служби у Збройних Силах України”; Указом Президента України "Про Положення про проходження громадянами України служби у військовому резерві Збройних Сил України”; Постановою Кабінету Міністрів України "Про затвердження Порядку проведення військової підготовки громадян України за програмою підготовки офіцерів запасу" та ін.. Знайомлячись з цими офіційними документами, потенційний вступник на навчання за програмою підготовки офіцерів запасу не отримує відповідей на виникаючі у нього запитання щодо професійного відбору, вимог до професійної діяльності, кола обов'язків та рівня відповідальності за майбутньою військовою посадою, власних професійних перспектив. Інформаційно-аналітичний супровід сприяє професійному самовизначенню, результатом якого є усвідомлений вибір здобувачем бакалаврського ступеня програми підготовки офіцерів запасу. 
Інформаційно-аналітичний супровід повинен включати наступні компоненти. Інформаційно-презентаційні зустрічі кандидатів на навчання за програмою підготовки офіцерів запасу з офіцерами військового комісаріату. Під час таких зустрічей потенційні вступники мають можливість 3'ясовувати особливості та умови проходження військової служби офіцером як кадровим, так і резервістом, отримувати відповіді на запитання щодо вимог до професійної діяльності за тією чи іншою військово-обліковою спеціальністю, кола обов'язків та рівня відповідальності за можливою посадою, власних професійних перспектив.

Наступним компонентом інформаційно-аналітичний супроводу $є$ професіографічні екскурсіїі до військових частин кандидатів на навчання за програмою підготовки офіцерів запасу. Під час таких екскурсій потенційні вступники можуть спілкуватись з командирами взводів та командиром роти, знайомитись 3 повсякденною діяльністю взводу, 3'ясувати, що таке бойова підготовка і з якою метою вона здійснюється, дізнаватися про сутність ротного господарства та про види відповідальності військовослужбовців.

Третім компонентом інформаційно-аналітичний супроводу є самотестування потенційних вступників на професійне самовизначення та готовність до управлінської діяльності. Є Лодатко пропонує застосовувати тест Д. Холланда 3 визначення професійних типів особистості [24], або тест за методикою Свгена Клімова [8] тощо [9, с. 20].

Здійснення такого інформаційно-аналітичний супроводу сприятиме не лише формуванню розуміння кандидатами на здобуття військової освіти, що навчання за програмою підготовки офіцерів запасу забезпечує мобільність на ринку праці, а й усвідомлення того, що по закінченні навчання офіцер запасу має обов'язково відслужити строкову службу, тобто, долучитися до військової та службово-педагогічної діяльності.

Практика сьогодні свідчить, що багато осіб, які навчаються за програмою підготовки офіцерів запасу, усвідомлюють це на останньому році навчання. Тому запровадження інформаційно-аналітичного супроводу сприятиме усвідомленому професійному самовизначенню здобувачів, які приймають рішення навчатись за програмою підготовки офіцерів запасу. Вони усвідомлено будуть готуватися до виховної роботи з особовим складом дорученого їм підрозділу. 


\section{4. Формування комунікативної компетентності майбутніх офіцерів запасу}

У структурі професійної компетентності офіцера запасу можна визначити такі важливі напрями його професійного становлення: загальна компетентність (загальнокультурна, валеологічна, екологічна, інформаційна, економічна та технічна), методологічна компетентність (знання принципів, методів, форм пізнання як у межах відповідного фаху), бойова компетентність (прояв підготовленості особистості як військового та забезпечує іiі ефективну діяльність щодо виконання завдань із захисту Батьківщини), військово-технічна (здатність офіцера підтримувати озброєння та техніку в готовності до застосування), соціальна компетентність (передбачає здатність офіцера брати на себе відповідальність, бути активним суб'єктом у прийнятті рішень, у суспільному житті, у врегулюванні конфліктів ненасильницьким шляхом) та комунікативна компетентність (передбачає здатність офіцера опанувати важливим у професійній діяльності та суспільному житті усним і писемним спілкуванням, оволодіння кількома мовами, визначати замкнутий цикл передачі педагогічного впливу, психологічні закономірності між особової взаємодії й, зокрема, спілкування, соціально-психологічні механізми регуляції групової творчої діяльності) [13].

Зосередимо увагу на останній - комунікативній. На думку Ф. Бацевича, важливою складовою комунікативної компетентності кожної людини є знання комунікативних законів та вміння їх використовувати, а якщо необхідно - протистояти їм. Дослідник підкреслює, що комунікативна компетентність - це не лише комплекс знань, а й внутрішні можливості мовця, зокрема комунікативні інтенції (утримування в пам'яті сказаного та постійна кореляція плину спілкування 3 метою мовця), знання особистості співрозмовника, постійна орієнтація в умовах і ситуації спілкування, контроль за процесом спілкування, контроль власної мовленнєвої поведінки, емоцій, контроль над посткомунікативними ефектами [1].

Науковці В. Бєліков та Л. Крисін зазначають, що “крім власне граматики носій мови повинен засвоїти “ситуативну граматику”, яка приписує використовувати мову не лише відповідно до змісту лексичних одиниць і правил їхньої сполучуваності в реченні, але й залежно від характеру стосунків між мовцем та адресатом, від мети спілкування 
й інших чинників, які разом із власне мовними знаннями складають комунікативну компетентність носія мови" [2, с. 68].

Комунікативна компетентність $є$ досить широким, складним явищем, яке містить не лише мовленнєву діяльність, а й знання з культури спілкування, знання правил поведінки в соціумі, у колективі, досконале володіння етикетними формулами; вона тісно пов'язана з такими властивостями особистості як вихованість, тактовність, толерантність у спілкуванні. Так, В. Куніцина трактує комунікативну компетентність як “володіння складними комунікативними навичками і вміннями, формування адекватних умінь у нових соціальних структурах, знання культурних норм та обмежень у спілкуванні, знання звичаїв, традицій, етикету у сфері спілкування, дотримання правил поведінки, вихованість; орієнтацію в комунікативних засобах, що властиві національному, становому менталітету і виражають його, засвоєння рольового репертуару в межах певної професії' [6, с. 481].

Тож якими методами можна сформувати комунікаційні компетентності офіцерів запасу? В першу чергу офіцер повинен бути готовим i здатним професійно займатися військово-педагогічною діяльністю, що і становить фундамент його професійної діяльності загалом. Сучасні дослідники проблем підготовки офіцерів запасу дійшли висновку про необхідність формування й розвитку у студентів військових кафедр професійно-педагогічного інтересу як основи їх творчої спрямованості в роботі з майбутніми (потенційними) підлеглими. Потреба у сполученні управлінських функцій із передачею професійних знань, умінь і навичок іншим (наприклад, особовому складу) неодмінно спонукає до зростання мотивації учіння, у тому числі - інтересу до навчально-пізнавальної діяльності. Під професійно-педагогічним інтересом розуміють сукупність зв'язків майбутнього офіцера з підлеглими, колегами, військовим колективом, тобто об'єктами і суб'єктами професійно-педагогічної діяльності, і одночасно - позитивне емоційне ставлення до них і до самої цієї діяльності.

Набуті офіцерами професійно-комунікативні уміння нададуть їм можливість міжкультурної взаємодії, що може втілюватися у життя в рамках вивчення дисциплін гуманітарного циклу. На нашу думку, взаємодія гуманітарних та фахових дисциплін допоможе підготувати висококваліфікованих офіцерів, готових до вирішення професійних, 
професійно-комунікативних та інженерно-технічних проблем. Для готовності офіцерів запасу до спілкування на міжнародному рівні формування професійної іншомовної компетентності має відбуватися інтегровано, у поєднанні з військовими та гуманітарними дисциплінами. Ми керуємося тим, що центральною ідеєю інтегрованого підходу є розвиток критичного мислення як конструктивної інтелектуальної діяльності.

Л. Пелепейченко зауважує, що для сучасного офіцера як лідера i оратора, значущим $€$ володіння мовною культурою, або мовним досвідом. Мова як засіб спілкування і передачі інформації має свої норми і свої особливості використання. Останні залежать від мовної ситуації i визначаються культурою мовлення. Точно сформульований наказ, стилістично і граматично правильно побудоване зауваження, доречно вжиті етикетні вислови - усе це характеризує мовну культуру офіцера. Тому існує необхідність навчання мовної культури, розвитку таких комунікативних умінь і навичок, які б відповідали загальним етичним вимогам та етикетним нормам нашого суспільства, а також формування розуміння важливості культури спілкування, оскільки поза нею руйнується взаємодія людей, їх виробнича діяльність. Мовний етикет визначається як система прийнятих у суспільстві стійких формул спілкування, призначених для встановлення мовного контакту співрозмовників, для підтримання спілкування в обраній тональності відповідно до їх соціальних ролей, відповідно до взаємних стосунків у офіційних і неофіційних умовах [11].

Практика наставництва, або менторінгу (від лат. mentor - вихователь, керівник), сьогодні сприймається науковцями як соціальний інститут адаптації в освітній галузі, або інноваційна компетентність педагога [6].

Наставництво у військові сфері ми розуміємо, як систему індивідуальної роботи курсанта $з$ досвідченим офіцером, спрямовану на його розвиток, адаптацію до бойових умов, психологічну готовність, шляхом передання знань, умінь і навичок від більш досвідченого колеги, тобто наставника. Ми вважаємо що при визначенні поняття «військове наставництво» слід враховувати практичні нюанси: взаємозв'язки між курсантами кафедри військової підготовки закладів вищої освіти та досвідченими військовослужбовцями у процесі передачі знань, умінь 
і бойових навичок, що проявляється у формі індивідуального, колективного, формального або неформального шефства, яке нерозривно пов'язане $з$ професійною підготовкою, адаптацією курсантів і розвитком їхнього військового потенціалу.

Необхідність формування майбутнього офіцера як суб'єкта діяльності в аспекті комунікаційної освіти розглядається у трьох напрямках: у напрямі педагогіки співробітництва, створення умов для самовиховання, активної діяльності самого курсанта. Через формування комунікативних умінь, що лежать в основі професійної діяльності, як і через приклад командира, пізнається військова справа, формується ідеал офіцера, уявлення про характер службових стосунків, закладаються звички професійного спілкування.

Узагальнюючи викладене, важливими чинниками, що зумовлюють основні принципи роботи щодо формування комунікативної компетентності офіцерів запасу у сучасних закладах вищої освіти України можна назвати: педагогіку співробітництва, особистісно-орієнтоване виховання, активну особисту позицію майбутнього офіцера запасу, критичне мислення, формування мовної культури та вплив наставників. Саме комунікативна компетентність майбутнього офіцера запасу сприятиме позитивному впливу офіцера на підлеглих та успішному проведенню виховної роботи у дорученому йому підрозділі.

\section{5. Використання комп'ютерних технологій при підготовці офіцерів запасу до виховної роботи}

Використання інформаційних, інфокомунікаційних технологій та засобів імітаційного моделювання у підготовці військових фахівців стало необхідною передумовою досягнення навчальної мети та засобами, які підносять педагогічну діяльність на якісно новий рівень. Світовий досвід і практика доводять необхідність впровадження у підготовку військових сучасних інформаційних технологій, заснованих на досягненнях в галузі комп'ютерного моделювання [4, с. 247].

До того ж слід додати, що сама система підготовки студентів за програмою офіцерів запасу, яка здійснюється один день на тиждень протягом 2 років навчання має певні особливості: ті, хто навчається, недостатньо відчувають атмосферу військового середовища, слабо уявляють роботу з підлеглим особовим складом. Така специфіка перед- 
бачає якомога більш широке застосування імітаційних, ситуаційних, мультимедійних й інформаційних технологій у навчальному процесі.

Учені А.Й. Дерев'янчук та О.Ф. Супрун також звертають увагу на те, що «стимулювання здатності студента до підвищення ефективності майбутньої професійної діяльності у військах убачається у постійному вдосконаленні та впроваджені у навчальний процес нових форм і методів навчання. Для підвищення ефективності навчання обов'язково треба сформувати й розробити для студентів відповідні мотиваційні стимулятори формування успішної діяльності, що спонукають до успіху, формують і поступово розвивають професійний інтерес i культуру фахової управлінської діяльності в цілому» [7, с. 27].

Інформатизація військової освіти розглядається як система заходів, що дозволяє внести суттєві зміни у психолого-педагогічні аспекти навчання, оскільки значно розширює можливості подання навчальної інформації, а саме: дозволяє підсилювати мотивацію навчання; активно залучає курсантів (слухачів) у процес набуття знань, вмінь та навичок; розширює комплекс навчальних завдань; посилює контроль за діяльністю курсантів (слухачів) та забезпечує гнучкість управління процесом навчання; сприяє формуванню у курсантів (слухачів) рефлексії своєї діяльності, насамперед, дозволяє їм наочно представити результат своїх дій; відтворює реальну обстановку завдяки використанню мультимедійних засобів [14, с. 52].

Останнім часом у навчальному процесі українських вишів активно використовуються сучасні засоби реалізації комп’ютерних технологій навчання: електронний навчально-методичний комплекс дисципліни (ЕНМК) та віртуальний лабораторний комплекс (комп'ютерна імітаційна модель - ВЛК).

ЕМНК - основний структурний компонент інформаційно-методичного забезпечення підготовки військового фахівця. Він покликаний забезпечити вирішення таких основних завдань: формування, вдосконалення та підтримання на необхідному рівні знань, умінь і навичок, визначених кваліфікаційними вимогами до підготовки військових фахівців в умовах, аналогічних штатним;

формування готовності тих, хто навчаються, застосовувати знання в інтересах службово-бойової діяльності, отримані з інших навчальних дисциплін; ілюстративна демонстрація можливих нештатних, екс- 
тремальних і нестандартних ситуацій у повсякденних і бойових умовах; контроль і відновлення рівня знань, умінь та навичок [5, с. 335].

Основою ВЛК $\epsilon$ комп'ютерна (імітаційна) модель - адекватна або наближена модель реального процесу або явища, реалізована засобами інформаційних технологій та моделювання. Саме вони стали незамінними у навчанні військових фахівців: комп'ютерна демонстрація різноманітних процесів та сценаріїв ведення бойових дій; імітація явищ і процесів, проведення експериментів, здійснення яких в реальних умовах є занадто витратними [7].

Однією із сучасних інтерактивних педагогічних технологій, яка демонструє приклад інтеграції інформаційних технологій з існуючими ситуаційними педагогічними технологіями (рольова гра, ділова гра) є технологія web-quest, створена у США в 1995 році дослідниками Б. Доджем и Т. Марчем, які вперше визначили методичні вимоги для гіпертекстового web-quest.

Розглянемо web-quest як технологію, що поєднує ознаки IT та педагогічної ситуативної технології (рольової гри) та визначимо ії основні характеристики.

У класичному розумінні - web-quest - проблемне завдання з елементами рольової гри для виконання якого використовуються інтернет-технології. Як відомо, інтернет-технології - це технології подання інформації у комп'ютерній мережі Інтернет, основою яких є гіпертексти, сайти, блоги, тощо; рольова гра - одна з педагогічних ситуативних технологій. Як правило, web-quest охоплює окрему проблему, навчальний предмет, тему, але може бути і міжпредметним. Розрізняють два типи web-quest: для короткочасної роботи (призначеної для вивчення окремої теми) і тривалої роботи (наприклад, глибоке вивчення теми протягом навчального року). Web-quest застосовується переважно для самостійної роботи курсантів (студентів) або для групової роботи (у мікрогрупах до 5 осіб) [3].

Високу ефективність щодо підвищення якості знань, умінь та навичок військового фахівця на кафедрах військової підготовки вищого закладу освіти забезпечує застосування таких інноваційних методів, форм і прийомів навчальної роботи, як метод конкретних ситуацій (МКС), або кейс-метод та моделювання. Метод конкретних ситуації передбачає прийняття студентами конкретного рішення 
у запропонованій ситуації. Для ефективного використання цього методу інформація, що міститься в кейсі, має відтворювати проблему з точки зору майбутньої професійної діяльності військового і може бути розв'язана декількома варіантами. Кожна група студентів у результаті обговорення пропонує свій варіант розв'язання проблеми, обгрунтовуючи його на основі отриманих знань 3 відповідної навчальної дисципліни.

До числа інноваційних технологій навчання військових фахівців належить технологія імітаційного моделювання, яка сприяє формуванню професійних якостей майбутніх фахівців через занурення в конкретну ситуацію, змодельовану в навчальних цілях. Головною особливістю імітаційного моделювання є ігровий характер: у процесі рольової взаємодії відбувається вирішення навчальних завдань, обмін знаннями та вміннями. У процесі використання комп'ютерних моделей реалізуються їх дидактичні функції, до яких відносяться: інформаційна, структурно-систематизуюча, інтерактивна функції та функція закріплення, контролю і самоконтролю. Наприклад, комп'ютерна (імітаційна) модель адекватна або наближена модель реального процесу або явища, реалізована засобами інформаційних технологій та моделювання. Незамінними у навчанні військових фахівців $є$ комп'ютерна демонстрація різноманітних процесів та сценаріїв ведення бойових дій, імітація явищ і процесів, проведення експериментів тощо [12].

Отже, використання сучасних інформаційних технологій у підготовці офіцерів запасу до виховної роботи створює реальні можливості підвищення якості військової освіти. Інформаційні технології дозволяють реалізувати принципи диференційованого та індивідуального підходу до навчання під час самостійної роботи. Одним з ефективних засобів удосконалення рівня підготовки військових фахівців є застосування сучасних електронних навчально-тренувальних комплексів різноманітного призначення, зокрема, віртуальних комп'ютерних комплексів та комп'ютерних (імітаційних) моделей. Вони, передусім, повинні сприяти осмисленню та засвоєнню навчального матеріалу, а також забезпечити можливість всебічної оцінки готовності майбутнього офіцера запасу до самостійної діяльності, своєчасне внесення індивідуальних коректив у підготовку військового фахівця. 


\section{6. Роль індивідуалізації навчання у підготовці офіцерів запасу}

Індивідуалізація навчання визначає додаткові можливості навчально-виховного процесу: створювати позитивні емоції в студента, позитивно впливати на його навчальну мотивацію та особистісні відносини у навчальній групі. Тому покращення навчальної мотивації й розвиток пізнавальних інтересів також можна вважати специфічною метою індивідуалізації. На зміст індивідуалізації як соціально-педагогічного процесу, істотний вплив здійснюють вимоги до випускників військових кафедр, обумовлені специфікою військової професії.

С.В. Сінкевич зазначає, що «Із всієї сукупності визначень “індивідуалізації навчання” вимогам теорії й практики військової підготовки майбутніх офіцерів запасу найбільш повно, на нашу думку, відповідатиме таке його визначення - це врахування у процесі навчання індивідуальних особливостей студентів у всіх формах і методах навчально-виховного процесу із переважним акцентом на кінцевий (позитивний) результат вирішення військово-професійних завдань» [20, с. 270].

У військовій дидактиці було зроблено спробу визначити загальні підходи до проблеми індивідуалізованої самостійної роботи майбутніх офіцерів запасу. Провідними є дві позиції. Відповідно до першої, запропоновано враховувати те, що індивідуалізація навчання являє собою комплекс методів, що застосовуються науково-педагогічним складом з метою розвитку творчого мислення, а також ініціативи, самостійності, рішучості, тобто якостей, необхідних для професійної діяльності. Друга позиція зводиться до того, що індивідуалізація навчання - це така організація навчального процесу, за якої вибір методів, форм, прийомів і засобів навчання здійснюється з урахуванням індивідуальних особливостей студентів. Автори цього підходу основний акцент зосередили на пошуку нових психодіагностичних моделей й удосконаленні організації навчально-виховного процесу.

Принцип індивідуального підходу в дидактиці передбачає урахування таких якостей студентів, які впливають на їхню навчальну діяльність і від яких залежать результати професійної підготовки загалом. Тому в контексті виявлення цих якостей у майбутніх офіцерів запасу 
при індивідуалізації навчання центральне місце посідає діагностика їхніх пізнавальних здібностей і можливостей. Індивідуальний стиль пізнавальної діяльності розглядається як один із психологічних механізмів засвоєння студентами знань, набуття умінь і навичок, а формування самого стилю пізнання - як один із важливих резервів підвищення ефективності навчання.

Отже, при реалізації індивідуалізації навчання майбутніх офіцерів запасу варто спиратися на такі основні методичні засади зазначеного процесу: організація додаткових занять із студентами, які мають прогалини в знаннях, за допомогою організації факультативних занять; здійснення індивідуалізації на різних етапах навчального заняття, спрямованої на те, щоб забезпечити єдиний темп групової роботи, єдиний рівень засвоєння знань та єдиний ступінь самостійності; пошук способів здійснення індивідуалізації навчання в рамках конкретного заняття через активну пізнавальну діяльність - відтворення опорного матеріалу при фронтальній роботі над темою, використання карток навчального характеру, наочного матеріалу, включення слабких до складу підгруп добре підготовлених студентів для виконання певних завдань прикладного характеру.

\section{7. Висновки}

Підбиваючи підсумок, вважаємо за потрібне наголосити, що військова освіта має забезпечувати умови для формування та самореалізації особистості, гнучкість і варіативність навчання, виважену гуманітарну спрямованість, значущість та престиж військової служби. Кінцевим результатом діяльності усіх рівнів військової освіти $\epsilon$ всебічно освічена особистість, яка адекватно сприймає реальність, має системний світогляд і аналітичне мислення, здатна приймати оптимальні рішення відповідно до профілю своєї військово-професійної діяльності.

Сформувати таку особистість прагнуть кафедри військової підготовки закладів вищої освіти України. Це офіцери запасу. Провідною особливістю військово-професійної діяльності військового керівника $є$ домінуюча професійна спрямованість, яка проявляється в організації виховної роботи з особовим складом і активній міжособистісній взаємодії,. У зв'язку з цим офіцер запасу повинен 
мати широке розвинуте практичне мислення та управлінську компетентність. Службово-педагогічна діяльність майбутнього офіцера запасу спрямована на організацію військового виховання та навчання, розвиток, психологічну підготовку і самовдосконалення особового складу, створення у майбутньому військовому колективі сприятливого педагогічного середовища, де кожен суб'єкт буде усвідомлювати відповідальність, як за власну підготовленість, так i за результати спільної діяльності.

Філософи та психологи виділяють п'ять основних видів діяльності: пізнавальну, перетворюючу (практичну та проектувальну), ціннісно-орієнтувальну, спілкування, естетичну. У цьому аспекті всебічний гармонійний розвиток особистості передбачає достатній рівень розвитку здібностей до одночасного здійснення всіх видів діяльності або, інакше кажучи, розвиток потенціалів особистості, які відповідають цим п’яти основним видам діяльності. Таким чином, структура професійної компетентності офіцера запасу, як і будь-якого іншого фахівця, має включати завдання всіх п’яти загальних видів професійної діяльності та, крім того, виражати специфіку військово-професійної й управлінської діяльності. На це спрямовані теорія і практика підготовки майбутніх офіцерів запасу до виховної роботи.

Щоб досягти успішного результату, навчально-виховний процес, спрямований на підготовку майбутніх офіцерів запасу, повинен будуватися на таких складових: інформаційно-аналітичний компонент підготовки майбутніх офіцерів запасу; формування комунікативної компетентності майбутніх офіцерів запасу; використання комп'ютерних технологій при підготовці офіцерів запасу до виховної роботи; індивідуалізація навчання.

Саме така організація освітнього процесу під час навчання на кафедрі військової підготовки офіцерів запасу, позитивно впливає і на продуктивність діяльності майбутнього командира взводу (групи, екіпажу), і на кінцевий іiі результат - на достатній рівень сформованості його професійної готовності до виконання бойових завдань за призначенням та до виховної роботи з особовим складом.

Здійсненню офіцерами запасу виховної роботи з особовим складом дорученого підрозділу (взводу, групи, екіпажу) у реальній діяльності буде присвячено наступні дослідження. 


\section{Список літератури:}

1. Бацевич Ф.С. Основи комунікативної лінгвістики : підручник. Київ, 2004. $344 \mathrm{c}$.

2. Беликов В.И. Социолингвистика : учеб. для вузов. Москва, 2001. 315 с.

3. Быховский Я.С. Образовательные веб-квесты. URL: http://www.iteach.ru/ met/metodika/a_2wn4.phpx (дата звернення: 18.10.2020).

4. Гапеєва О.Л. Аналіз основних тенденцій управління збройними силами в інформаційну епоху. Третя Всеукраїнська науково-технічна конференція "Перспективи розвитку озброєння і військової техніки Сухопутних військ"13-14 квітня 2010 р., м. Львів. С. 247.

5. Гапеєва О.Л. Застосування web-quest технологій у навчальному процесі студентів за програмою офіцерів запасу. Вісник ЛНЛТУ. 2011. Випуск 21.1. С. 335-340.

6. Денисенко Н.Г., Смірнов С.В. Компетентнісно-орієнтоване наставництво як засіб інноваційної підготовки майбутніх офіцерів запасу в умовах ВН3. Молодий вчений. 2016. № 12. С. 413-416.

7. Дерев'янчук А.Й., Супрун О.Ф. Мотивація і стимулювання студентів кафедр військової підготовки в умовах обмежених часом і озброєнням. Імідж сучасного педагога. 2014. № 7. С. 24-27.

8. Климов Е.А. Образ мира в разнотипных профессиях : учеб. пособие. Москва, 1995. 222 с.

9. Лодатко Є. Організаційно-педагогічні умови формування інформаційно-аналітичної компетентності та професійного самовизначення здобувачів освіти - майбутніх офіцерів запасу. Молодь і ринок. 2019. № 8(175). С. 16-22.

10. Мацевко Т. М. Особливості мотивації майбутніх офіцерів запасу до службово-педагогічної діяльності. Молодий вчений. 2018. №1. С. 353-357.

11. Мовна комунікація в діяльності сил охорони правопорядку: теоретичні засади галузевої комунікації : Монографія / За редакцією Л.М. Пелепейченко. Харків : АВВ МВС України, 2008. 270 с.

12. Моца А.А. Інноваційні технології навчання у вищій військовій освіті України: практичне застосування. Интернаука. 2017. № 5. С. 26-34.

13. Олійник Л.В. Концептуальні підходи до визначення структури професійної компетентності сучасного офіцера Збройних Сил України. Військова освіта. 2013. № 1. С. 159-166.

14. Пасмор Н. Деякі питання формування і розвитку електронного навчального середовища ВВНЗ. Вища школа: науково-практичне видання. 2008. № 8. С. 49-54.

15.Про Державну програму розвитку Збройних Сил України на період до 2020 року : Указ Президента України від 22 березня 2017 року № 73/2017. URL: https://zakon.rada.gov.ua/laws/show/73/2017\#n2 (дата звернення: 22.10.2020).

16. Про затвердження Інструкції про організацію військової підготовки громадян України за програмою підготовки офіцерів запасу : наказ Міноборони України, МОН України від 14.12.2015 № 719/1289. URL: https://zakon.rada.gov.ua/ laws/show/z1678-15\#Tеxt (дата звернення: 19.10.2020).

17.Про затвердження Положення про військові навчальні підрозділи закладів вищої освіти : наказ Міністерства освіти науки, Міністерства обо- 
рони України від 15 серпня 2018 р. № 910/412 / Офіщійний вісник України. 2018. № 91. С. 89-101.

18.Про затвердження Порядку проведення військової підготовки студентів вищих навчальних закладів за програмою підготовки офіцерів запасу: постанова Кабінету Міністрів України від 1 лютого 2012 р. № 48. URL: https://zakon.rada.gov.ua/laws/show/48-2012-п\#Техt(дата звернення: 21.10.2020).

19.Про рішення Ради національної безпеки і оборони України від 20 травня 2016 року "Про Стратегічний оборонний бюлетень України” : Указ Президента України від 6 червня 2016 року № 240/2016. URL: https://www.president.gov.ua/documents/2402016-20137 (дата звернення: 22.10.2020).

20.Сінкевич С.В. Методичні засади індивідуалізації навчання майбутніх офіцерів запасу. Збірник наукових праць Національної академії Державної прикордонної служби України. Серія : Педагогічні та психологічні науки. 2013. № 1. C. 269-276.

21.Староконь Є.Г. Формування інтерактивної складової професійного спілкування у майбутніх офіцерів : автореф. дис. ... канд. психол. наук : 19.00.07. Київ, 1993. 23 с.

22. Телелим В.М., Тимошенко Р., Приходько Ю. Військова освіта в системі безпеки та оборони держави. Наука і оборона. 2013. № 4. С. 21-29.

23. Телелим В.М., Приходько Ю.І. Система військової освіти: протиріччя розвитку, напрями та шляхи реформування. Наука і оборона. 2012. № 4. C. 42-46.

24. Holland, J.L. Occupational Finder. N.-Y. : Psychological Assessment Resources, Inc., 1994. 42 p.

\section{References:}

1. Batsevich F.S. (2004). Osnovy komunikativnoi lingvisniky: pidruch. [Fundamentals of communicative linguistics textbook]. Kyiv: Akademiya. (in Ukrainian)

2. Belikov V.I. (2001). Sotaiolingvistika: ucheb. dlya vuzov [Sociolinguistics: textbook for universities]. Moscow. (in Russian)

3. Bihovskiy Y.S. Obrazovatelniye veb-kvesti [Educational web quests]. URL: http://www.iteach.ru/met/metodika/a_2wn4.php (accessed 18.10.2020).

4. Gapeyeva O.L. (2010). Analiz osnovnih tendentsiy upravlinnya zbroynimy silamy v informatsiynu epohu [Analysis of the main tendencies in the management of large forces in the information era]. Third All-Ukrainian Science and Technology Conference «Prospects for the development of planting and technology for land flights» (April 13-14, 2010, m. Lviv). Lviv. (in Ukrainian)

5. Gapeyeva O.L. (2011). Zastosuvannya web-quest tehnologiy u navchalnomu protsesi studentiv za programoyu ofitseriv zapasu [Stagnation of web-quest technologies in the initial process of students for the program of reserve officers]. Visnik LNLTU, vol. 21, pp. 335-340.

6. Denisenko N.G., Smirnov S.V. (2016). Kompetentnisno-oriyentovane nastavnitstvo yak zasib innovatsiynoi pidgotovky maibutnih ofitseriv zapasu v umovah VNZ 
[Competently-organized mentorship for the innovative training of the maybutnich officers in the stock in the minds of the VNZ]. Young impressions, no. 12, pp. 413-416.

7. Derevianchuk A.Y., Suprun O.F. (2014). Motivatsiya I snymuluvannya studentiv kafedr viyskovoi pidgotovky v umovah chasom i ozbroyennyam [Motivation and stimulation of students in the departments of modern training in the minds of those who are interconnected by the hour and in the environment]. Imidzh of a modern teacher, no. 7, pp. 24-27.

8. Klimov Y.A. (1995). Obraz mira v raznotipnih professiyah: ucheb. posobiye [The image of the world in different types of professions: textbook allowance]. Moscow. (in Russian)

9. Lodatko Y. (2019). Organizatsiyno-pedagogichni umovy formuvannya informatsiyno-analtichnoi kompetentnosti ta profesiynogo samovyznachennya zdobuvachiv osvity - maibutnih ofitseriv zapasu [Organizational and pedagogical conditions for the formation of information and analytical competence and professional self-determination of students - future reserve officers]. Youth and the market, no. 8, pp. 16-22.

10. Matsevko T.M. (2018). Osoblivosti motyvatsii maibutnih ofitseriv zapasu do sluzhbovo-pedagogichnoi diyalnosti [Features of motivation of future reserve officers to service and pedagogical activity]. Young Scientist, no. 1, pp. 353-357.

11. Pelepeychenko L.M. (Ed). (2008). Movna komunikatsiya v diyalnosti sil ohorony pravoporyadku: Teoretichni zasady galuzevoi komunikatsii: Monografiya [Linguistic communication in the activities of law enforcement: Theoretical principles of sectoral communication: Monograph]. Kharkiv: AVV MVS. (in Ukrainian)

12. Motsa A.A. (2017). Innjvatsiyni tehnologii navchannya u vyshchiy viyskoviy osviti Ukrainy: praktychne zastosuvannya [Innovative learning technologies in higher military education of Ukraine practical applicftion]. Interscience, no. 5, pp. 26-34.

13. Oliynik L.V. (1913). Kontseptualni pidhody do viznachennya struktury profesiynoi kompetentnosti suchasnogo ofitsera Zbroynih Syl Ukrainy [Conceptual approaches to determining the structure of professional competence of a modern officer of the Armed Forces of Ukraine]. Military education, no. 1, pp. 159-166.

14.Pasmor N. (2008). Deyaki pytannia formuvannia i rozvitku elektronnogo navchalnogo seredovishcha VVNZ [Some issues of formation and development of e-learning environment of higher education institutions]. Higher school: scientific and practical edition, no. 8, pp. 49-54.

15. On the State Development Program of the Armed Forces of Ukraine for the period up to 2020: Decree of the President of Ukraine of March 22, 2017 № 73/2017. URL: https://zakon.rada.gov.ua/laws/show/73/2017\#n2 (accessed 22.10.2020).

16. On approval of the Instruction on the organization of military training of citizens of Ukraine according to the training program of reserve officers: order of the Ministry of Defense of Ukraine, MES of Ukraine dated 14.12.2015 № 719/1289 URL: https://zakon.rada.gov.ua/laws/show/z1678-15\#Text (accessed 19.10.2020).

17. On approval of the Regulations on military training units of higher education institutions: Order of the Ministry of Education of Science, Ministry of Defense of Ukraine of August 15, 2018 № 910/412. Official Gazette of Ukraine, no. 91, pp. 89-101. 
18. On approval of the Procedure for conducting military training of students of higher educational institutions under the reserve officers training program: Resolution of the Cabinet of Ministers of Ukraine of February 1, 2012 № 48. URL: https://zakon.rada.gov.ua/laws/show/48-2012-n\#Text (accessed 21.10.2020).

19. On the decision of the National Security and Defense Council of Ukraine of May 20, 2016 "On the Strategic Defense Bulletin of Ukraine": Decree of the President of Ukraine of June 6, 2016 № 240/2016. URL: https://www.president.gov.ua/ documents/2402016-20137 (accessed 22.10.2020).

20. Sinkevich S.V. (2013). Metodichni zasady indyvidualizatsii navchannia maibutnih ofitseriv zapasu [Methodical bases of individualization of training of future reserve officers]. Collection of scientific works of the National Academy of the State Border Guard Service of Ukraine. Series: Pedagogical and psychological sciences, no. 1, pp. 269-276.

21. Starokon Y.G. (1993). Formuvannya interaktivnoi skladovoi profesiynogo spilkuvania u maibutnih ofitseriv [Formation of an interactive component of professional communication in future officers]: author. ref. dis. ... cand. psychol. science. Kyiv. (in Ukrainian)

22. Telelim V.M., Timoshenko R., Prihodko Y. (2013). Viiskova osvita v sistemi bezpeky ta oborony derzhavy [Military educftion in the security and defense system of the state]. Science and defense, no. 4, pp. 21-29.

23. Telelim V.M., Prihodko Y.I. (2012). Sistema viyskovoi osvity: pronyrichchia rozvytku, napriamy ta shliahy reformuvannia [the system of military education: contradictions of development, directions and ways of reform]. Science and defense, no. 4, pp. 42-46.

24.Holland, J.L. Occupational Finder. N.-Y.: Psychological Assessment Resources, Inc., 1994. 42 p. 